\title{
KONSEP MANAJEMEN MUTU TERPADU DALAM PENDIDIKAN
}

\author{
Hairiyah \\ Prodi PAI STIA Alma Ata Yogyakarta \\ Email: hairiyahhamid@gmail.com
}

\begin{abstract}
Abstrak
Total quality Management (TQM) as a management tips that focus on process improvement of customer satisfaction, which is deemed successful in the industrialized world began to demand institutions to be adapted with the aim of producing a "product" of quality. In the perspective of education MMT is an organization that provides services and products in the form of (service). Every individual in an organization that is implementing (TQM) is a manager in any sphere of competence. In the context of education, the improvement is not only done by the government but also carried out by the staff of the administration by the improvement of the system and the culture of administrative services, and also by teachers with the learning process improvement. Thus, students are regarded as one of the customers will be able to feel satisfaction in the service of the institution.
\end{abstract}

Keywords: Continuous improvement, total involvement, customer satisfaction

\section{PENDAHULUAN}

Pendidikan adalah merupakan suatu masalah yang sangat penting dalam kehidupan manusia. Maju tidaknya suatu bangsa sangat tergantung pada pendidikan bangsa tersebut. Artinya jika pendidikan suatu bangsa dapat menghasilkan manusia yang berkualitas lahir batin. Otomatis bangsa tersebut akan maju, damai dan tentram. Sebaliknya jika pendidikan suatu bangsa mengalami stagnasi maka bangsa itu akan terbelakang disegala bidang. Dalam hal ini E. Mulyasa menyatakan bahwa:

Pendidikan memberikan kontribusi yang besar terhadap kemajuan suatu bangsa, dan merupakan wahana dalam menerjemahkan pesan-pesan konstitusi serta sarana dalam membangun watak bangsa (Nation Character Building). Masyarakat yang cerdas akan memberi nuansa kehidupan yang cerdas pula, dan secara progresif akan membentuk kemandirian. Masyarakat bangsa yang demikian merupakan investasi besar untuk berjuang ke luar dari krisis dan menghadapi yang global. 
Kita tahu bahwa pendidikan dalam bentuk, jenis dan ragamnya telah dilaksanakan oleh sepanjang sejarah manusia itu sendiri, namun pada kenyataannya pendidikan yang mampu menghasilkan sumber daya yang berkualitas belum sepenuhnya direalisasikan. Hal ini dapat kita lihat pada fenomena yang ada, selalu terjadi kontradiksi antara cita dan fakta antara idealita dan realita. Salah satu faktor penyebab dari kontradiksi di atas adalah pada pengelolaan lembaga pendidikan itu sendiri. Disamping banyak faktor lain, faktor pengelolaan akan sangat menentukan produktivitas dan efektivitas lembaga pendidikan. Pendidikan sebagai sebuah sistem tidak akan mampu menghasilkan output yang berkualitas, apalagi proses pendidikan tersebut tidak dikelola secara baik. oleh karena itu pendidikan harus dikelola secara profeisonal, agar mampu berkompetisi dan mampu menjawab segala tantangan global.

Tentunya ini menjadi sebuah tatangan bagi kita semua, khususnya para praktisi pendidikan. Dalam menyikapi tantangan tersebut diperlukan paradigma baru dalam pendidikan. Sebagaimana pernyataan Kuhn yang dikutip oleh Tilaar, menyatakan bahwa;

Apabila tantangan-tantangan baru itu dihadapi dengan menggunakan paradigma lama maka segala usaha yang dijalankan akan mendapatkan kegagalan. Begitu juga halnya dengan pendidikan, apabila ingin mendapatkan keberhasilan harus di desain ulang (rekonstruksi) supaya dapat menjawab tantangan serta perubahan saat ini (modern) baik pada sisi konsepnya, kurikulum, kualitas sumber daya manusianya, lembaga- lembaga, dan organisasinya namun yang paling penting adalah manajemen pendidikannya itu sendiri, yang paling prioritas untuk direkonstruksi agar relevan dengan perubahan zaman dan tuntutan pasar.

Di sisi lain, perkembangan pendidikan saat ini menuntut orang tua pandai memilih pendidikan yang terbaik untuk anaknya, karena pendidikan di samping mementingkan faktor kognitif, psikomotorik, dan afektif juga perlu mempertimbangkan masalah faktor moralitas sehingga meningkatkan kompetisi, pilihan, dan pelaku pendidikan mempengaruhi pendidikan hari ini.

Pendidikan yang berkualitas merupakan salah satu faktor penunjang kepuasan siswa. Termasuk juga orang tua, orang tua akan menjadi puas ketika anaknya memperoleh pendidikan yang berkualitas yang diberikan oleh pihak sekolah.

Tentu saja hal tersebut menjadi tantangan yang sangat besar bagi lembaga pendidikan saat ini. Lembaga pendidikan dituntut untuk menghasilkan Output yang berkualitas yang salah satunya dengan meningkatkan mutu 
proses pengelolaan pelayanan di mana proses akan berpengaruh terhadap output. Untuk itu demi perbaikan manajemen, dunia pendidikan saat ini mulai mengadopsi satu teori manajemen dunia industri yang berkembang di Amerika dan Jepang, yaitu Total Quality Management (TQM) atau atau yang kita kenal dengan sebutan Manajemen Mutu Terpadu (MMT). Ketika pemerintah memberi kesempatan kepada otoritas sekolah untuk mengoptimalkan seluruh potensinya sehingga peningkatan kualitas banyak dicapai, banyak sekolah yang kemudian berupaya menerapkan MMT tersebut.

\section{PEMBAHASAN \\ Manajemen Mutu Terpadu (MMT) Dalam Pendidikan Sejarab Manajemen Mutu Terpadu}

Sejarah Manajemen Mutu Terpadu (MMT) sangat tidak lepas dengan sejarah Total Quality Management (TQM), karena seperti yang di uraikan penulis sebelumnya bahwa Manajemen Mutu Terpadu adalah terjemahan dari Total Quality Management itu sendiri. Sejarah Manajemen Mutu Terpadu berawal dari perjalanan industri Jepang yang mengalami kehancuran total akibat Perang Dunia II. Untuk membangun kembali dan bangkit dari kehancuran industrinya tersebut, pada tahun 1950 Asosiasi Insinyur Jepang mengundang William Edward Deming yang dikenal sebagai "Bapak Mutu" untuk melatih para insinyur Jepang dalam bidang manajemen untuk mencapai mutu, yang kemudian dikenal dengan Total Quality Management.

Deming mengajarkan bahwa barang atau jasa bermutu adalah yang dapat memenuhi kebutuhan para pelanggan. Oleh karena itu, dalam mengadakan barang atau jasa yang bermutu, kebutuhan pelanggan harus diketahui terlebih dahulu dengan sebaik-baiknya. Berdasarkan pengetahuan itulah lalu kemudian dibuat rencana pengadaan barang atau jasa, dan pembuatannya pun harus sesuai dengan rencana itu. Karena kebutuhan pelanggan berubah-ubah dari waktu ke waktu, maka mutu barang atau jasa pun juga berubah. Maka dari itu, mutu itu tidak absolut, tidak berakhir pada mutu itu sendiri, melainkan harus selalu ditingkatkan secara terus-menerus, sehingga senantiasa dapat memenuhi kebutuhan pelanggan. Mutu yang demikian itu adalah mutu yang bersifat relatif. Inilah yang dimaksud mutu dalam MMT.

Konsep Deming tersebut di atas ternyata cukup berhasil di Jepang, justru di negaranya sendiri yaitu Amerika Serikat, tidak mendapat perhatian sebelum Perang Dunia II, karena para industriawan di Amerika Serikat telah puas denga keberhasilan mereka. Namun setelah industri Jepang, terutama pada industri mobil merajai pasar dunia, baru mereka sadar akan pentingnya pemikiran Deming. Mereka mulai mempelajarinya kembali lalu kemudian menerapkannya. 
Beberapa prinsip pokok dari deming yang dapat diterapkan dalam bidang pendidikan adalah: a. Anggota dewan sekolah dan administrator harus menetapkan tujuan mutu pendidikan yang akan dicapai. b. Menekankan pada upaya pencegahan kegagalan pada siswa, bukannya mendeteksi kegagalan setelah peristiwanya terjadi. c. Asal diterapkan secara ketat, penggunaan metode kontrol statistik dapat membantu memperbaiki outcomes siswa dan administratif. ${ }^{1}$

Dr. Joseph M. Juran pun diakui sebagai salah satu seorang "Bapak Mutu". Juran menyebut mutu sebagai "tepat untuk pakai" dan menegaskan dasar dasar misi mutu sebuah sekolah adalah mengembangakan program dan layanan yang memenuhi kebutuhan pengguna seperti siswa dan masyarakat. Pandangan Juran tentang mutu merefleksikan pendekatan rasional yang berdasarkan fakta terhadap organisasi bisnis dan amat menekankan pentingnya proses perencanaan dan kontrol mutu. Titik fokus filosofi manajemen mutunya adalah keyakianan organisasi terhadap produktivitas individual. Mutu dapat dijamin dengan cara memastikan bahwa setiap individu memiliki bidang yang diperlukannya untuk menjalankan pekerjaan yang tepat. Dengan perangkat yang tepat, para pekerja akan membuat produk atau jasa yang secara konsisten sesuai dengan harapan pelanggan.

Seperti halnya Deming, Juran pun memainkan peran penting dalam membangun kembali Jepang setelah perang Dunia II. Dia diakui jasanya oleh bangsa Jepang dalam mengembangkan kontrol mutu di Jepang dan memfasilitasi persahabatan Amerika Serikat dan Jepang. Upaya Juran menemukan prinsipprinsip dasar proses manajemen membawanya untuk memfokuskan diri pada mutu sebagai tujuan utama. Beberapa pandangan Juran tentang mutu adalah: a. Meraih mutu merupakan proses yang tidak mengenal akhir. b. Perbaikan mutu merupakan proses berkesinambungan, bukan program sekali jalan. c. Mutu memerlukan kepemimpinan dari anggota dewan sekolah dan admistrator. d. Pelatihan masal merupakan persyaratan mutu. e. Setiap orang di sekolah harus mendapatkan pelatihan. ${ }^{2}$

Sesuai dengan perkembangannya mutu memiliki tahapan-tahapan, sebagaimana Husaini Usman dalam bukunya ............ menyebutnya dengan hirarki mutu. Adapun hirarki mutu tersebut ialah: a. Inspeksi, yaitu menjaga mutu dengan ketelitian pengawas. b. Quality Control (QC), yaitu menjaga mutu dengan pendeteksian. c. Quality Assurance (QA), yaitu menjaga mutu dengan cara

${ }^{1}$ Jerome S. Arcaro, Pendidikan Berbasis Mutu: Prinsip-Prinsi p Perumusan dan Tata Langkah Penerapan (Yogayakarta: Pustaka Pelajar, 2007), hlm. 8.

${ }^{2}$ Ibid., hlm. 9. 
pencegaban. d. Total Quality Management (TQM), yaitu menjaga mutu dengan cara terus-menerus. e. Wide Quality Management (WQM), yaitu memecahkan masalah mutu. ${ }^{3}$

Kelima hirarki mutu tersebut dapat digambarkan sebagai berikut.

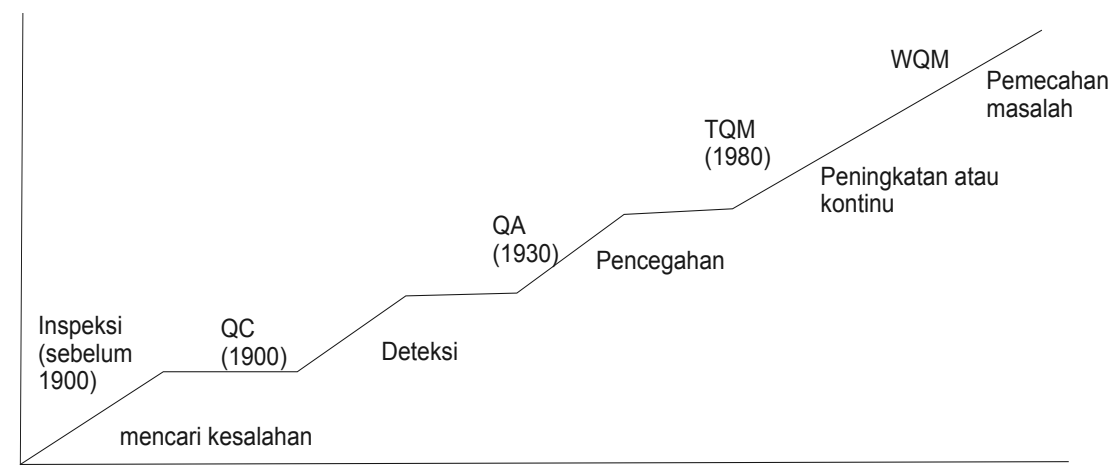

Gambar 1. Hirarki Mutu

\section{Mutu dalam Manajemen Mutu Terpadu}

Definisi mutu memiliki konotasi yang bermacam-macam tergantung orang yang memaknainya. Mutu berasal dari bahasa Latin, qualis yang artinya what kind of. Mutu menurut Deming ialah kesesuaian dengan kebutuhan pasar. Mutu menurut Juran ialah kecocokan dengan produk. Sedangkan menurut Crosby ialah kesesuaian dengan yang disyaratkan. ${ }^{4}$ Adapun mutu menurut Peters dan Austin adalah nafsu dan kebanggaan. ${ }^{5}$ Perusahaan raksasa IBM mendefinisikan mutu sebagai kepuasan pelanggan. Serupa dengan perusahaan raksasa lainnya, salah satunya Ford Motor mendefinisikan mutu ialah memuaskan pelanggan sepuas-puasnya. ${ }^{6}$

Edward Sallis sendiri membagi mutu menjadi dua konsep, yaitu konsep yang relatif dan absolut. Mutu yang absolut ialah mutu yang idealismenya tinggi dan harus dipenuhi, berstandar tinggi, dengan sifat produk bergengsi tinggi, biasanya mahal, sangat mewah, dan jarang dimilki orang. Mutu dengan konsep absolut berarti harus high quality atau top quality. Sedangkan mutu yang relatif menurut Sallis bukanlah sebuah akhir, namun sebagai sebuah alat

${ }^{3}$ Husaini Usman, Manajemen Teori Praktik Dan Riset pendidikan (Jakarta: Bumi Aksara, 2008), hlm 482

${ }^{4}$ Ibid., hlm. 477.

${ }^{5}$ Edward Sallis, Total Quality Manajemen In Education: Manajemen Mutu Pendidikan, terj. (Yogyakarta: IRCiSoD, 2008), hlm. 29.

${ }^{6} I b i d .$, hlm. 31. 
dimana produk atau jasa dinilai, yaitu apakah telah memenuhi standar yang telah ditetapkan atau tidak, artinya sesuatu dapat dikatakan bermutu selama produk tersebut secara konsisten sesuai dengan tuntunan pembuatannya. ${ }^{7}$

Setiap orang selalu mengharapkan bahkan menuntut mutu dari orang lain, sebaliknya orang lain juga selalu mengharapkan dan menuntut mutu dari diri kita. Ini artinya, mutu bukanlah sesuatu yang baru, karena mutu adalah naluri manusia. Benda dan jasa sebagai produk dituntut mutunya, sehingga orang lain yang menggunakan puas karenanya. Dengan demikian, mutu adalah paduan sifatsifat dari barang atau jasa, yang menunjukkan kemampuannya dalam memenuhi kebutuhan pelanggan, baik kebutuhan yang dinyatakan maupun yang tersirat.

Benda dan jasa sebagai hasil kegiatan manusia yang secara sadar dilakukannya disebut "kinerja". Kinerja itulah yang dituntut mutunya, sehingga muncul istilah "mutu kinerja manusia". Suatu kinerja disebut bermutu jika dapat menemuhi atau melebihi kebutuhan dan harapan pelanggannya. ${ }^{8}$ Oleh karena itu, maka suatu produk atau jasa sebagai kinerja harus dibuat sedemikian rupa agar dapat memenuhi kebutuhan dan harapan pelanggannya yang ditandai dengan kepuasan.

Adapun ciri-ciri manajemen mutu (sebagai bentuk pelayanan pelanggan), sebagaimana yang dikehendaki dalam MMT yaitu ditandai dengan: ketepatan waktu pelayanan, akurasi pelayanan, kesopanan dan keramahan (unsur menyenangkan pelanggan), bertanggung jawab atas segala keluhan pelanggan, kelengkapan pelayanan, kemudahan mendapatkan pelayanan, variasi layanan, pelayanan pribadi, kenyamanan, dan ketersediaan atribut pendukung. ${ }^{9}$

Sedangkan sifat-sifat pokok mutu jasa, menurut Slamet adalah mengadung unsur-unsur:

\section{Keterpercayaan (Reliability)}

Keterpercayaan dapat dihasilkan dari sikap dan tindakan seperti: jujur, tepat waktu pelayanan, terjaminnya rasa aman dengan produk/jasa yang dipergunakan/ diperoleh, dan ketersediaan produk/jasa saat dibutuhkan pelanggan.

\section{${ }^{7}$ Ibid., hlm. 51-54}

${ }^{8}$ Lihat http://mujtahid-komunitas pendidikan. Blogspot.com/2010/02/tqm-dalampendidikan-islam. Html.

${ }^{9}$ Margono Slamet, Manajemen Mutu Terpadu dan Perguruan Tinggi Bermutu (Yogyakarta: Pustaka Pelajar, 1994), hlm. 72-74. 
Keterjaminan (Assurance)

Keterjaminan suatu mutu jasa dapat ditimbulkan oleh kondisi misalnya penghasil produk/jasa memang kompeten dalam bidangnya, obyektif dalam pelayanannya, tampil dengan percaya diri dan meyakinkan pelanggannya. Penampilan (Tangibility).

Penampilan adalah sosok dari produk/jasa dan hasil karyanya. Misalnya bersih, sehat, teratur dan rapi, enak dipandang, serasi, berpakaian rapi dan harmonis, dan buatannya baik.

\section{Perhatian (Emphaty)}

Empati adalah berusaha merasakan apa yang dialami oleh pelanggan ("seandainya saya dia"). Cara berempati dapat dinyatakan dengan penuh perhatian terhadap pelanggan, melayani dengan ramah dan memuaskan, memahami keinginan pelanggan, berkomunikasi dengan baik dan benar, dan bersikap penuh simpati.

Ketanggapan (responsiveness)

Adapun ketanggapan adalah ungkapan cepat tanggap dan perhatian terhadap keluhan pelanggan. Ungkapan tersebut dapat dinyatakan dengan cepat memberi respon pada permintaan pelanggan dan cepat memperhatikan dan mengatasi keluhan pelanggan. ${ }^{10}$

\section{Organisasi Manajemen Mutu Terpadu (MMT) dalam pendidikan}

Organisasi MMT dalah organisasi terbalik (upside-down organization). Pembalikan peta hierarki organisasi tradisional menjadi organisasi terbalik diadopsi dari pemikiran Albretcht yang dipahami oleh Slamet mencoba memberikan sebuah pergeseran paradigma pada MMT dalam pendidikan. Dalam organisasi pendidikan, peran kepala sekolah adalah mendukung dan mengupayakan pendidikan bagi siswa dan staf pendukungnya, kontrol bukanlah yang utama. ${ }^{11}$

Dalam konteks pendidikan, MMT merubah pola hubungan dengan memberikan sebuah fokus pelanggan yang jelas. Fokus ini tidak berdampak pada struktur otoritas, dan ia juga tidak mengurangi peran kepemimpinan kepala sekolah. Hirarki terbalik menekankan pada pola hubungan yang berorientasi pada pemberian layanan dan pentingnya pelanggan bagi institusi. Di bawah ini adalah gambar hirarki institusi dan institusi terbalik dalam pendidikan.

\footnotetext{
${ }^{10}$ Ibid., hlm. 75

${ }^{11}$ Husaini Usman, Manajemen..., hlm. 544-545
} 


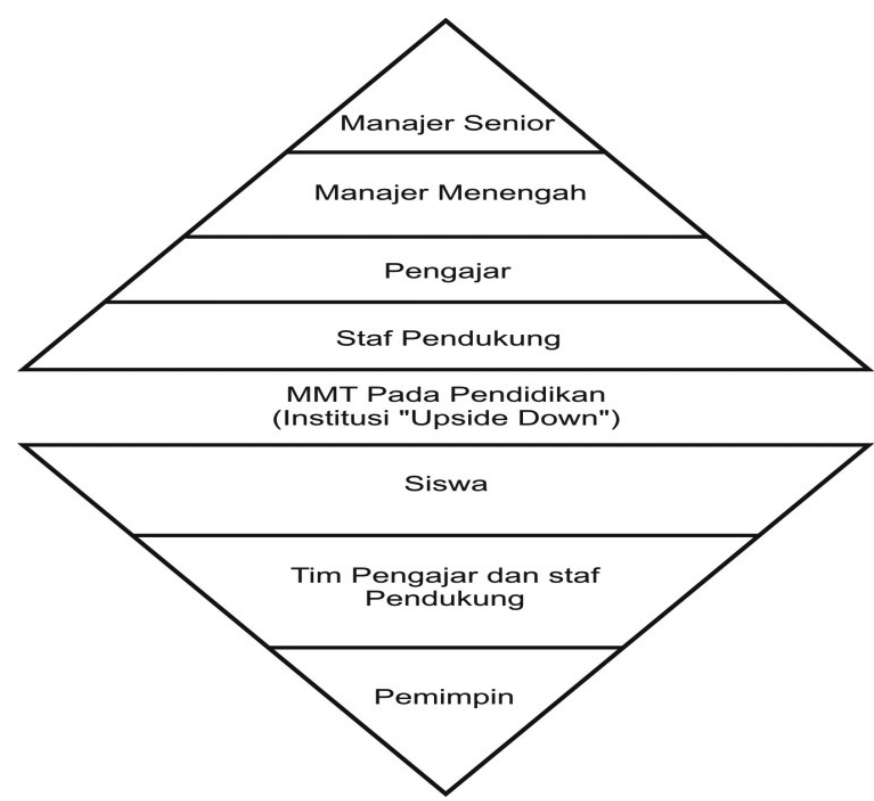

Gambar 2. Hirarki Institusi dan Institusi terbalik dalam pendidikan

\section{Kepemimpinan MMT dalam Pendidikan}

Spanbauer dalam bukunya Edward Sallis memberikan model kepemimpinan untuk memberdayakan pengajar sebagai berikut:

Melibatkan para guru dan seluruh staf dalam aktifitas penyelesaian masalah, dengan menggunakan metode ilmiah dasar, prinsip-prinsip mutu statistik dan kontrol proses.

Memilih untuk meminta pendapat mereka tentang berbagai hal dan tentang bagaimana cara mereka menjalankan proyek dan tidak sekedar menyampaikan bagaimana seharusnya bersikap.

Menyampaikan sebanyak mungkin informasi manajemen untuk membantu pengembangan dan peningkatan komitmen mereka.

Menanyakan pendapat staf tentang sistem dan prosedur mana saja yang menghalangi mereka dalam menyampaikan mutu kepada para pelanggan: pelajar, orangtua, dan patner kerja.

Memahami bahwa keinginan untuk meningkatkan mutu para guru tidak sesuai dengan pendekatan manajemen atas ke bawah (top-down).

Memindahkan tanggungjawab dan kontrol pengembangan tenaga profesional langsung kepada guru dan pekerja teknis.

Mengimplementasikan komunikasi yang sistematis dan kontinyu di antara setiap orang yang terlibat dalam sekolah. 
Mengembangkan kemampuan pemecahan masalah serta negosiasi dalam rangka menyelesaikan konflik.

Memiliki sikap membantu tanpa harus mengetahui semua jawaban bagi setiap masalah dan tanpa rasa rendah diri.

Menyediakan materi pembelajaran konsep mutu seperti membangun tim, manajemen proses, layanan pelanggan, komunikasi serta kepemimpinan. Memberikan teladan yang baik, dengan cara memperlihatkan karakteristik yang diinginkan dan menggunakan waktu untuk melihat-lihat situasi dan kondisi institusi dengan mendengarkan keinginan guru dan pelanggan lainnya.

Belajar untuk berperan sebagai pelatih dan bukan sebagai bos, Memberikan otonomi dan berani mengambil resiko.

Memberikan perhatian yang berimbang dalam menyediakan mutu bagi para pelanggan eksternal (pelajar, orang tua dan lainnya) dan kepada para pelanggan internal (pengajar, anggota dewan guru, dan pekerja lainnya. ${ }^{12}$

Sedangkan Peter dan Austin sebagaimana yang dipahami oleh Husaini Usman memberikan atribut kepemimpinan pendidikan sebagai berikut:

Visi dan simbol; kepala sekolah harus mengkomunikasikan nilai-nilai sekolah kepada seluruh warga sekolah dan masyarakat luas.

Management By Walking About (MBWA); ${ }^{13}$ gaya kepemimpinan ini dibutuhkan oleh setiap sekolah.

Untuk anak-anak (for the kids): istilah ini sama dengan "dekat dengan pelanggan" dalam pendidikan. Ini memastikan bahwa institusi memiliki fokus yang jelas terhadap pelanggan utamanya.

Otonomi, percobaan, dan memaafkan kesalahan; kepala sekolah harus berani mendorong inovasi guru dan staf tata usahanya untuk belajar dari kesalahan sehingga sekolah memiliki inovasi yang lebih baik.

Menciptakan suasana "kekeluargaan"; kepala sekolah membutuhkan komunikasi dalam suasana yang akrab penuh kekeluargaan dengan warga di sekolah dan di luar sekolah.

${ }^{12}$ Edward Sallis, Total Quality Management..., hlm. 176-178

${ }^{13}$ MBWA atau yang diistilahkan dengan "manajemen dengan melaksanakan" menekankan pentingnya kehadiran pemimpin dan pemahaman atau pandangan mereka terhadap karyawan dan proses institusi. Lihat: Edward Sallis, Total Quality Manajemen..., hlm. 170. 
Perasaan menyeluruh, irama, kemauan besar untuk mencapai tujuan sekolah, intensitas, dan penuh perhatian; hal ini adalah mutu personal mendasar yang dibutuhkan oleh pemimpin pendidikan. ${ }^{14}$

\section{Lembaga Pendidikan Bermutu Terpadu}

Bila diterapkan dengan tepat, MMT merupakan metodologi yang dapat membantu para profesional pendidikan menjawab tantangan lingkungan masa kini. MMT dapat dipergunakan untuk mengurangi rasa takut dan meningkatkan kepercayaan di lembaga pendidikan itu sendiri. Untuk menghantarkan sebuah lembaga menjadi lembaga pendidikan bermutu terpadu, Arcaro menawarkan lima pilar kinerja mutu, yaitu: 1) fokus pada pelanggan 2) keterlibatan total 3) pengukuran 4) komitmen dan 5) perbaikan berkelanjutan. Kelima pilar tersebut akan di uraikan di bawah ini.

\section{Fokus pada pelanggan}

Misi utama MMT adalah memenuhi kepuasan pelanggan. Mutu harus sesuai dengan persyaratan yang diinginkan pelanggan. Tanpa mutu yang sesuai dengan keinginan pelanggan, lembaga pendidikan akan kehilangan pelanggannya, dan pelanggan adalah raja yang harus dilayani dengan sebaikbaiknya.

Agar lembaga pendidikan mengembangkan fokus mutu, setiap individu harus mengakui bahwa setiap outpun lembaga pendidikan adalah pelanggan. ${ }^{15}$ Namun meskipun demikian, tidak dengan sendirinya merupakan sebuah kondisi yang mencukupi untuk meyakinkan bermutu total. Lembaga pendidikan masih butuh penyusunan strategi yang lengkap untuk menemukan persyaratan yang diinginkan pelanggan. ${ }^{16}$

\section{Keterlibatan total}

Setiap orang harus terlibat dalam transformasi mutu. Manajemen harus memiliki komitmen untuk memfokuskan pada mutu. Transformasi mutu diawali dengan mengadopsi paradigma baru pendidikan. Menurut Arcaro dalam bidang pendidikan memang sangat sulit bagi individunya untuk mengembangkan paradigma baru pendidikan. Ada dua keyakinan pokok yang menghalangi tiap upaya penciptaan mutu dalam sistem pendidikan. Pertama, banyak profesional pendidikan yakin bahwa mutu pendidikan bergantung

${ }^{14}$ Husaini Usman, Manajemen: Teori Praktik dan..., hlm. 544

${ }^{15}$ Jerome S. Arcaro, Pendidikan Berbasis Mutu..., hlm. 11.

${ }^{16}$ Husaini Usman, Manajemen: Teori Praktik dan..., hlm. 533. 
pada besarnya dana yang dialokasikan untuk pendidikan. Lebih banyak uang yang diinvestasikan dalam pendidikan maka lebih tinggi juga mutu pendidikan. Studi kasus mutakhir meruntuhkan keyakinan ini. Kedua, banyak profesional pendidikan secara terbuka menyatakan bahwa mereka memiliki komitmen terhadap tranformasi mutu Deming. Namun tindakan mereka menunjukkan, mereka tidak mengembangkan filosofi baru dalam pendidikan yang didasarkan pada 14 butir mutu Deming. ${ }^{17}$ Mutu pendidikan tidak akan mengalami perbaikan yang signifikan sampai ada penyelesaian terhadap kedua masalah tersebut.

\section{Pengukuran}

Secara tradisional ukuran mutu atas keluaran pada lembaga pendidikan adalah prestasi siswa. Ukuran dasarnya adalah hasil ujian. Bila hasil ujian bertambah baik, maka mutu pendidikan pun membaik. Para profesional pendidikan seharusnya belajar untuk mengukur mutu. Mereka perlu memahami pengumpulan dan analisa data yang diperlukan dalam proses pengukuran tersebut. Begitu mereka belajar mengumpulkan dan menganalisa data, maka mereka dapat mengukur dan menunjukkan nilai tambah pendidikan.

\section{Komitmen}

Setiap individu dalam lembaga pendidikan harus memiliki komitmen pada mutu. Bila mereka tidak memilki komitmen, proses transformasi mutu tidak akan dapat dimulai. Setiap orang perlu mendukung upaya mutu. Mutu merupakan perubahan budaya yang menyebabkan organisasi merubah cara kerjanya. Orang biasanya sulit untuk mau berubah, namun manajemen harus mendukung proses perubahan dengan memberi penndidikan, perangkat, sistem dan proses untuk meningkatkan mutu.

\section{Perbaikan berkelanjutan}

Konsep dasarnya, mutu adalah sesuatu yang dapat diperbaiki. Menurut filosofi manajemen lama, “ jika belum rusak, janganlah diperbaiki”. Mutu didasarkan pada konsep bahwa setiap proses dapat diperbaiki dan tidak ada proses yang sempurna. Menurut filosofi manajemen yang baru, “ jika belum rusak perbaikilah, karena bila anda tidak melakukannya orang lain pasti melakukannya”. Inilah yang disebut konsep perbaikan berkelanjutan atau dikenal pula dengan perbaikan terus-menerus. ${ }^{18}$

\footnotetext{
${ }^{17}$ Lihat: Edward Sallis, Total Quality Manajemen..., hlm. 100-103.

${ }^{18}$ Jerome S. Arcaro, Pendidikan Berbasis Mutu..., hlm.13-12.
} 
Untuk mengembangkan budaya perbaikan berkelanjutan, tugas pertama kepala sekolah adalah memberikan kepercayaan kepada warganya dan mendelegasikan kewenangan pada level yang sesuai agar stafnya turut bertanggung jawab terhadap peningkatan mutu. Perbaikan berkelanjutan oleh orang Jepang disebut kaizen. Kaizen diterjemahkan sebagai perbaikan sedikit demi sedikit, tetapi terus menerus. Esensi kaizen adalah memperbaiki yang kecil-kecil dan yang mudah-mudah dahulu, untuk mendapatkan keberhasilan. Dengan keberhasilan timbul rasa percaya diri untuk memperbaiki yang besarbesar. $^{19}$

\section{KESIMPULAN}

MMT merupakan konsep mengacu pada mutu yang berguna memuaskan pelanggannya. Dalam konteks pendidikan, suatu lembaga pendidikan dikatakan bermutu apabila antara pelanggan internal dan eksternal telah terjalin kepuasan atas jasa yang diberikan. Guna menjamin pengelolaan pelayanan yang mampu menghasilkan Output berkualitas. Berdasarkan uraian di atas sungguh sangat elok jika setiap pengelolaan pada lembaga pendidikan dilandaskan pada MMT yang pada dasarnya menekankan pada perbaiakan terus menerus dan kepuasan pelanggan untuk menghasilkan pendidikan yang berkualitas.

\section{DAFTAR PUSTAKA}

E. Mulyasa. 2002. Manajemen Berbasis Sekolah. Bandung: PT. Remaja Rosdakarya.

Edward Sallis.2008. Total Quality Manajemen In Education: Manajemen Mutu Pendidikan, terj. Yogyakarta: IRCiSoD.

Fasli Jalal dan Dedi Supriyadi. 2001. Reformasi Pendidikan dalam Konteks Otonomi Daerah. Yogyakarta: Adicita.

H. A. R. Tilaar. 1998. Beberapa Agenda Reformasi Pendidikan Nasional Dalam Perspektif Abad 21. Magelang: Tera Indonesia.

Husaini Usman. 2008. Manajemen Teori Praktik Dan Riset pendidikan. Jakarta: Bumi Aksara.

Jerome S. Arcaro. 2007. Pendidikan Berbasis Mutu: Prinsip-Prinsi Perumusan dan Tata Langkah Penerapan. Yogayakarta: Pustaka Pelajar.

Margono Slamet. 1994. Manajemen Mutu Terpadu dan Perguruan Tinggi Bermutu. Yogyakarta: Pustaka Pelajar.

${ }^{19}$ Husaini Usman, Manajemen: Teori Praktik dan..., hlm.531 